\section{5. 简易循環機能模枯についての一考宗}

横浜市立大学 $\bigcirc$ 遊佐 清有, 小川 義雄

片尾 周造, 里吉 政子

深屈滕運動負荷試験（旧学術研究会議体力班制定）は， 負荷が軽い，用具を必要としないといら特徴を持つてい るが，この負荷運動を現在広く実施されている踏及台昇 降と比べると，踏み台昇降化比し深屈伸運動負荷では負 荷運動に対する脈はくの変動が掘く，また回復も遅い㑯 向にあり，90秒以上の負荷では深屈滕運動負荷のほうが 負荷後の回復が遅い，旧学研法の規定では負荷後に 9 回 脈拍数を湘定するが，その合計脈拍数を判定指標とする かわりに運動直後より 2 分10秒までの脈拍数を用いるこ とができる，その際，同時に運動直後より15秒間の脈拍 数も記録すれば，運動中の脈拍数を推定することが可能 となる.

テストの簡略化をはかるとともに，判定に対する信頼 性を高めようとする立場を考えると，体力テストに含ま れる各種の負荷，たとえば50メートル走などの直後にも 脈拍数の湘定を実施することが望ましい，踏み台だけが 㡒環機能判定の必要用具ではない，多くの種類の負荷運 動を利用し，多角的に綜合判定を求めることが必要であ
る. その際に判定をより理解しやすくする試みとして, 横軸に時問 $(t)$ をとり維軸に累積脈拍数 $(p)$ をとる 四のよらな四表を作つてみた。フイールド・ワークにお いては図の（ $\left.\mathrm{t}_{3}, \mathrm{p}_{3}\right)$ を原点とする 四表を 利用する。こ れは運動終了時点で， $\mathrm{p}_{4}-\mathrm{p}_{3}$ から運動中の脈拍数を推 定することも可能である．負荷運動量を增大させてもA のよらな限界があり，一般にDとAとの間において変動 する（ただし水銀柱加圧試験ではDより下に外れること あある).

負荷と脈拍数の変化

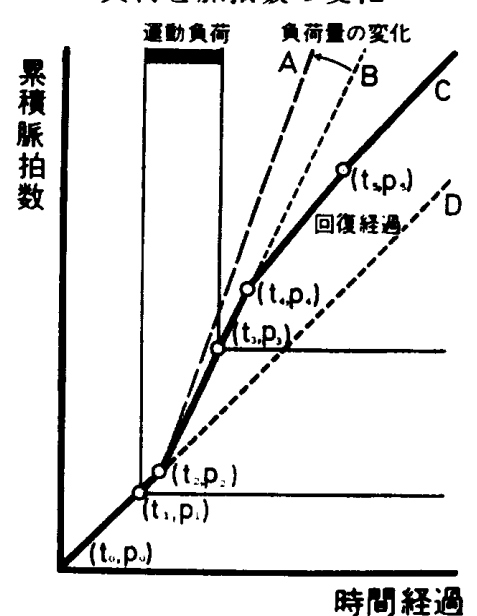

416. エレクトロニクス,カウンターによる疾走能力に関 すろ分析的研究(第 3 報)一特に時定数を中心とした一 東京教育大学 $\bigcirc$ 浅川 正一, 武政喜代次 古藤 高良, 岡岡 康雄 山西 哲郎, 佐々木秀幸 長谷川宏一, 岡田 泰士

はじめに 疾走速度に 関する研究は，1894 年 E.J. Marey に初包, 1927年 A.V. Hill の研究によつて, ト 方法的には頂点に達した感がある。われわれは、ェレク 二ロクス,カウンターに上る電気的記録法に上る各種の 報告を行なつて来たが，木年度は制御工学における時定 数の考え方を基碄として，発育段階と速度俰数の関連を 检討し，2，3 の知見を得たので報告する。

- 本研究に使用した榙出器湘定装置は, 水晶発振器か らの同波数安定度 $10^{-\boldsymbol{s}}$ 篙精度同波数を用い,多イオー ドを組み合わせた電気パルスで、スタート、ストップの 制御回路を作り、カウンターに送る仕組みとなつてい る. 制御回路に送られる出力は、フオト、トランヂスタ 一の出力である.。被験者：被験者の選択条件として, 運動能力, 体格等の面から平均的水潐化ある学校群つ選 択から始め、それそれれの条件を十分に满たするのとし て, 千葉県津田小学校, 東京代々木中学格、神奈川電発 学園高校の男女, 1230 名を当てた。 - 榙查项目 所定の 隻備運動終了後, 垂㨁跳, 全身反応時間の測を実施し, それそれの検查終了後, 50M M全力疾走負何に上る検査 を実施した。一結果と考家 発青段階別最高速度差仙， 学年ことの発達, 停滞を明確に示した。.小学校 6 年〜中 学 1 年の間には， $0.79 \mathrm{~m} / \mathrm{sec}$ ついで中学 3 年〜高校 1 年: では $0.73 \mathrm{~m} / \mathrm{sec}$ とそれぞれ大きな增加を示している。 女子では，小学校 6 年〜中学 1 年の間に $0.94 \mathrm{~m} / \mathrm{sec}$ と 非常に大きな場加を示し，次いで，中学 3 年〜高校 1 年. の間に一- $0.59 \mathrm{~m} / \mathrm{sec}$ と大な減少を示した。次いで, 最高速度と, スタート後 $10 \mathrm{~m}$ の平均速度は，小学校で は $\mathrm{r}=0.92$, 中, 高枍では $\mathrm{r}=0.91$ 之1\%水準にありて, $99 \%$ 以上の有意性を示した。これらの相関表から，最富 速度と平均速度 (0〜10m) は, 性別, 発育段階に関係な
く，一次的に直線增加を示していることが判明した。こ れらの検查結果から，速度俰数=平均速度 $(0 \sim 10 \mathrm{~m})$ $=0.55$ と云万值を得た，われわれは，此の速度俰数を もとに，小学校〜高等学校までのスタート後 $10 \mathrm{~m}$ のタ イムから，個人の持つている最高，50m 速度予想夕イ 么表を作製した。

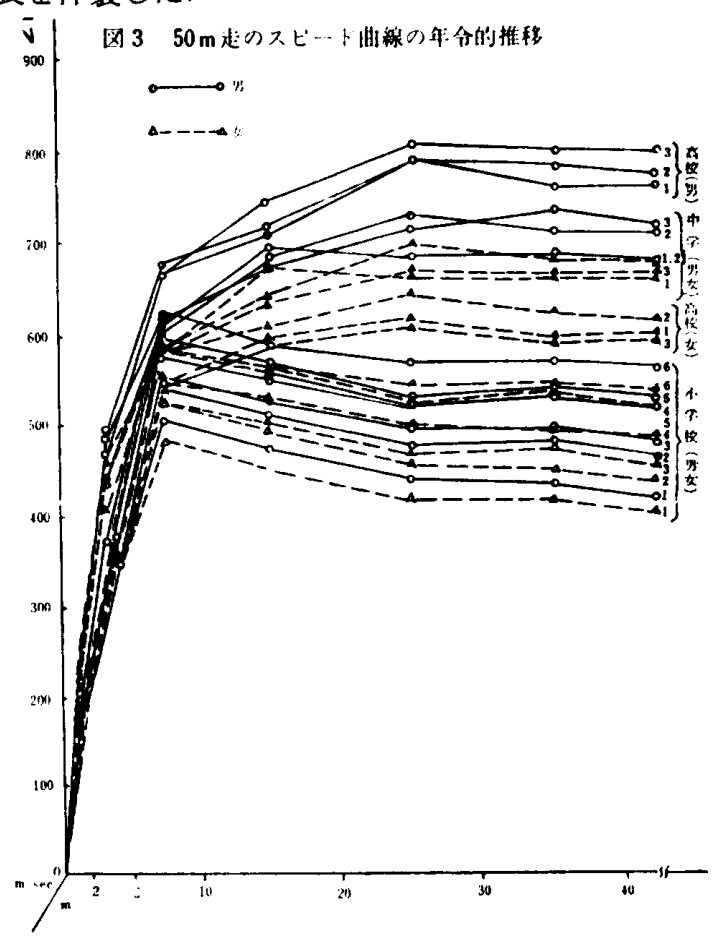

